\title{
A Perspective On The Measurement Of INFLATION CREDIBILITY
}

\author{
J Rossouw ${ }^{1}$ \\ Reserve Bank and University of Pretoria \\ F Joubert ${ }^{2}$ \\ Department of Economics, University of Pretoria
}

\begin{abstract}
Inflation targeting anchors inflation expectations, which are not within the sphere of control of the authorities, but can only be influenced over time by consistent policy. As public distrust of inflation figures will feed through to inflation expectations, this paper highlights a comparison of the credibility of two different measures of inflation in terms of an inflation credibility barometer. In a comparison of the barometer results to the analysis of inflation perceptions reported by other central banks, it is concluded that the barometer delivers superior results. The main recommendation is that respondents should be requested in a follow-up study to indicate whether they attach a higher degree of credibility to the overall inflation rate or the rate used for targeting purposes.
\end{abstract}

JEL E31, E52, E58

\section{Background}

A recent article in the South African Journal of Economics, titled "Supporting an inflation targeting policy with the measurement of inflation credibility" (Rossouw \& Joubert, 2005: Vol 73: 2), highlights the results of two pilot studies aimed at the compilation of an inflation credibility barometer in support of the anchoring of inflation expectations. Inflation targeting anchors inflation expectations, which are not within the sphere of control of the authorities, but can only be influenced over time by consistent policy. As a result, public distrust of inflation figures will feed recursively through to inflation expectations.

Keeping the above perspectives in mind, the authors compiled questionnaires to highlight a comparison of the credibility of two different measurements of inflation through the use of the inflation credibility barometer. The aim was to reiterate some of their earlier recommendations with respect to the use of an inflation credibility barometer.
Two of the three recommendations and some observations of the earlier study are summarised in section two of this paper, as well as some observed initiatives of other central banks in measuring or improving inflation credibility. The methodology followed in designing a questionnaire for testing these two recommendations is discussed in section three. The findings are discussed in section four. Section five highlights the conclusions and recommendations.

\section{2}

\section{Some earlier recommendations and observed initiatives}

Based on two different pilot studies involving three separate groups of students at the University of Pretoria, Rossouw and Joubert (2005) recommended ${ }^{3}$, inter alia, that:

(i) an abridged questionnaire, asking only one question about the perceived accuracy of a rate of inflation, should be used to measure the credibility of inflation and compile an 
inflation barometer, as the use of such a questionnaire achieved the highest degree of acceptance of the stated inflation data as a true measure of price increases in the previous pilot studies; and

(ii) the respondents should be split into two groups, and only one question should be put to each group: the overall rate of inflation in one instance and the rate used for inflation targeting in the second instance, to test a hypothesis that broad media coverage of the rate of inflation used for inflation targeting purposes results in a higher reading of the inflation credibility barometer.

The anchoring and measurement of inflation expectations is of importance to central banks within an inflation-targeting country. Expectations are informed over time by the policy actions of the authorities and are sampled by means of opinion polls; an approach that has been followed in South Africa since 1999 (Kershoff \& Smit, 2002: 445).

Inflation expectations are formed by and large through the historic policy decisions of central banks and their success in containing inflation, rather than through public announcements of the future intentions of the central bank. According to Mishkin “... an essential ingredient to a successful anti-inflation policy is the credibility of the policy in the eyes of the public ..." (2004: 658). One approach to achieve this objective could be to make the central bank “... more independent from government and to charge it with the single responsibility of achieving and maintaining the price level" (Parkin, 1999: 809; see also Mishkin, 2004: 352-354). De Wet (2003: 799) confirms the view that "... the more independent the central bank is, the lower the inflation rate will be", citing a number of studies that had all found that "... independence and inflation are highly negatively correlated".

In instances where countries have been successful in containing inflation, central banks are not only allowed instrument independence in achieving the goal of price stability, but inflation expectations have also been contained successfully. Lacker (2005) states “ ... low and stable inflation expectations have enhanced the ability of monetary policy to react flexibly to both positive and negative shocks ...". Any lack of credibility of published inflation figures will therefore serve as an early warning of a possible change in inflation expectations, as " ... a central bank ... does not have control over expectations of inflation" (Mishkin, 2004: 419). If the general public does not accept the rate of inflation as a true reflection of price increases in an economy, the benefits of anchoring inflation expectations in the current rate of inflation could therefore be forfeited in the long run (Rossouw, 2005: 298).

Important examples of central banks measuring inflation perceptions are the Swedish Riksbank (established in 1668 and therefore the world's oldest central bank), the European Central Bank (ECB), which recently turned five and is one of the youngest central banks in the world, and the Reserve Bank of New Zealand (the first central bank to adopt an inflation target).

The Swedish Riksbank has surveyed “ ... households' perspectives on current and future price developments" (Palmqvist et al., 2004) since 1978. Respondents are requested to indicate whether they perceive prices to be the same, higher or lower than a year before and the Riksbank publishes an average perception of the accuracy of current inflation.

The ECB uses surveys of European consumers by the European Commission to measure and report on changes in perceptions of the accuracy of current inflation data. The survey results are summarised as a balance statistic, computed on the difference in percentage points between respondents reporting perceptions of higher cost of living and those reporting unchanged or lower cost of living (European Central Bank, 2005: 30).

The Reserve Bank of New Zealand's quarterly questionnaire on inflation expectations included a question on the credibility of the inflation rate since December 1987, but reporting on recorded perceptions was improved in 1995.

The Bank publishes the mean and median of the perceptions reported by the respondents (Reserve Bank of New Zealand, 2005). 
Whereas these three central banks measure inflation perceptions, Mexico focuses on the improvement of the credibility of the measurement of inflation figures through the certification of the procedures used (Banco de Mexico, [S.a.]).

In the next section the design of questionnaires for use in a further study aimed at measuring the credibility of inflation figures in South Africa is highlighted.

\section{3}

\section{Questionnaire for the measurement of inflation credibility}

Based on the recommendation for the use of an abridged questionnaire to compile an inflation credibility barometer (Rossouw \& Joubert, 2005: 333), two questionnaires, attached as Annexures A and B, were developed to measure inflation credibility. Respondents were requested to identify themselves in the completed questionnaire for control purposes and to prevent a situation where one respondent could complete more than one questionnaire.

One of the three groups of respondents surveyed previously was again selected to complete the questionnaires. The reasons for using the specific group of respondents are twofold. Firstly, the respondents are a relatively large group of students from different backgrounds, which is thus in a sense representative of the larger community. Secondly, the students, compared to the general public, have above-average knowledge of what inflation is and how it is measured. They could thus complete the questionnaire with knowledgeable reasoning.

Both questionnaires contain only one question on inflation, providing the latest relevant inflation figure to respondents, as
Kershoff and Smit (2002: 453) state that "(t)he benefit of providing historical information is that all respondents have the same information available when completing the questionnaire ... (as) ... historic information provides respondents with a benchmark". Respondents were requested to indicate whether the stated figure is a true reflection of average price increases. The one questionnaire provides the most recent official overall inflation figure (changes in the consumer price index in metropolitan and other urban areas, i.e. CPI) and the other provides the most recent inflation figure used for inflation targeting purposes (changes in the consumer price index in metropolitan and other urban areas excluding changes in mortgage interest cost, i.e. CPIX). The respondents were randomly split into two groups and each group completed one of the questionnaires.

The purpose of using two questionnaires was to compare which measure of inflation recorded the higher degree of acceptance on the inflation credibility barometer. The completed questionnaires are assessed in the next section.

\section{4}

\section{Completion of questionnaires and survey results}

The two questionnaires were completed by the same group of second-year students following the EKN 215 course at the University of Pretoria as in the study of inflation credibility in the earlier article (Rossouw \& Joubert, 2005). Based on experience gained from the earlier survey, it was considered unnecessary to use more than one group of respondents. The sample comprised 81 EKN 215 students and their responses are highlighted in Annexures C and $\mathrm{D}$. The result is summarised in figure 1 . 


\section{Figure 1}

Inflation credibility: Summary results of the surveys of the credibility of

$\mathrm{CPI}$ and CPIX, respectively

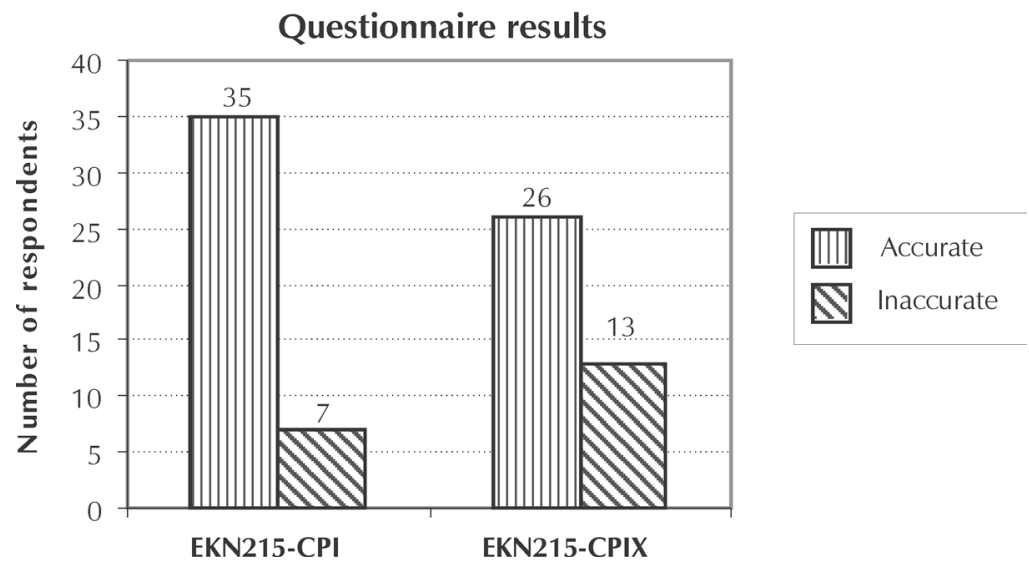

The credibility barometer for students who completed the questionnaire stating the CPI reads 83 (out of a possible 100), as 35 out of 42 students accepted the CPI as an accurate indication of current inflation. In respect of CPIX, the barometer reads 67, as 26 students out of 39 accepted it as accurate.

As the research has a binary outcome variable for the dependable variable, i.e. the response can either be YES or $N O$, the results obtained from the completed questionnaires were evaluated by means of the Statistical Analysis System (SAS), with an aim to estimate the probability of obtaining either answer. The specific method used was the calculation of a two-way frequency table using the Proc Frequency (PROC FREQ) procedure. Frequency tables show the distribution of variable values. Cross-tabulation tables show combined frequency distributions for two or more variables. For two-way tables, as in this case, PROC FREQ computes tests and measures of association. PROC FREQ can use either raw data or cell-count data to produce frequency and cross-tabulation tables. Raw data, also known as case-record data, report the data as one record for each subject or sample member (SAS, 1999-2001: help files). The analysis is highlighted in Table 1 below.

\section{Table 1}

Results of the Proc Freq procedure summary of the total pilot studies

The SAS System

The FREQ Procedure

\begin{tabular}{|l|l|c|c|c|}
\hline \multirow{2}{*}{$\begin{array}{l}\text { Frequency } \\
\text { Percent } \\
\text { Row Pct }\end{array}$} & \multirow{2}{|l|}{ Table of Defaults by Study } & \\
\cline { 2 - 4 } Col Pct & \multirow{2}{*}{ Defaults } & $\mathbf{2 1 5 C P I}$ & $\mathbf{2 1 5 C P I X}$ & \multirow{2}{*}{ Total } \\
\cline { 2 - 5 } & \multirow{2}{*}{ no } & 7 & 13 & 20 \\
& 8.64 & 16.05 & 24.69 \\
& 35.00 & 65.00 & \\
& 16.67 & 33.33 & \\
& & &
\end{tabular}




\begin{tabular}{|l|l|l|c|}
\hline yes & 35 & 26 & 61 \\
& 43.21 & 32.10 & 75.31 \\
& 57.38 & 42.62 & \\
& 83.33 & 66.67 & 81 \\
\hline Total & 42 & 39 & 100.00 \\
\hline
\end{tabular}

To compare the results in each of the groups separately in Figure 2, the column percentage ('Col Pct') should be considered. In respect of the measurement of the credibility of CPI data (215CPI), the probability of a YES response is 83.33 per cent versus a probability of 16.67 per cent for a $N O$ response. In respect of the CPIX data (215CPIX), the probability of a YES response is 66.67 per cent and that of a $N O$ response is 33.33 per cent.

In comparing the outcome between the two groups, the total percentages (Percent) should be considered. The probability of a YES response in the CPI group is 43.21 per cent versus the probability of 32.1 per cent for a YES response in the CPIX group. Clearly, there is a higher probability of a YES in the CPI group, which indicates that the credibility of the CPI figure is higher than the credibility of the CPIX figure.

\section{5}

\section{Conclusions and recommendations}

This study's first conclusion is that a higher degree of acceptance of CPI than of CPIX as an accurate indication of inflation was recorded. This does not confirm the hypothesis that the public attention focused on the inflation rate used for targeting purposes increases its credibility.

Secondly, an abridged questionnaire rather than the long questionnaire used in earlier pilot studies and highlighted in the earlier article (Rossouw \& Joubert, 2005: 327, 328, 333) delivers more useful results. Credible results from this group of respondents confirm that the abridged questionnaire is suitable for use with larger groups of respondents to establish the credibility of published inflation figures.
The third conclusion is that the inflation credibility barometer delivers superior results to the approaches followed by other central banks and by Mexico, in as much as it (i) provides an immediate indication of the degree of acceptance of the accuracy of current inflation data, (ii) highlights any change in the degree of such acceptance over time at each occasion of measurement, and (iii) is easily understood by the general public.

The first recommendation is that the appropriate rate of inflation to use for measuring inflation credibility and constructing the barometer should be clarified by using the abridged questionnaire to put two questions to each respondent in a sample, i.e. one question about the level of the CPI and another about the CPIX, and requesting them to indicate whether none, one or both the rates are perceived as an accurate indication of current price increases. In this way, clarity on the use of a particular rate of inflation for use in the compilation of the credibility barometer could be ascertained and communication of that measure should be improved.

The second recommendation is that countries using inflation targets should consider measuring the credibility of inflation by means of an inflation credibility barometer serving as an early indication of any possible delinking of inflation expectations from the current rate of inflation.

\section{Endnotes}

\footnotetext{
SA Reserve Bank and Economics Department of the University of Pretoria. The valuable comments and remarks of a senior colleague at the Reserve Bank on an earlier draft of this paper are gratefully acknowledged, but any errors or omissions remain the responsibility of the authors.
} 
2 Economics Department of the University of Pretoria.

3 A third recommendation dealt with the specification of the inflation rate used for targeting purposes in South Africa, i.e. CPIX. The opinions and views expressed are those of the authors and do not necessarily represent those of either the Reserve Bank or the University.

\section{References}

1 BANCO DE MEXICO ([S.a]) [Ista na Internet] http://www.banxico.org.mx/inpc/ [Obtido 23 June 2005] Translation assistance by Ms I. Gaspar, S A Reserve Bank.

2 DE WET, W.A. (2003) "Thinking like a Governor: Central banking under an inflation target”, The South African Journal of Economics, December, 71:4.

3 EUROPEAN CENTRAL BANK (2002) Monthly Bulletin, July.

4 EUROPEAN CENTRAL BANK (2003) Monthly Bulletin, October.

5 EUROPEAN CENTRAL BANK (2005) Monthly Bulletin, April.

6 HOWARD, G. (2005) E-mail received from $\mathrm{Mr}$ Graham Howard of the Reserve Bank of New Zealand at Graham.Howard@rbnz.govt.nz, 20 June.

7 KERSHOFF, G.J. \& SMIT, B.W. (2002) "Conducting inflation expectation surveys in South Africa”, The South African Journal of Economics, March, 70:3.

8 LACKER, J.M. (2005) Inflation Targeting and the Conduct of Monetary Policy. Remarks by the President of the Federal Reserve Bank of Richmond at the University of Richmond, Virginia. [Online]. http://www.rich.frb.org/media/speeches/index.cfm/ $\mathrm{id}=70$ [Accessed 7 March 2005].

9 MISHKIN, F.S. (2004) The Economics of Money, Banking and Financial Markets, $7^{\text {th }}$ ed. AddisonWesley: United States of America.

10 PALMQVIST, S. \& STROMBERG, L. (2004) "Households' inflation opinions: A tale of two surveys", Sveriges Riksbank Economic Review 4, Available online at http://www.riksbank.com/ upload/Dokument_riksbank/Kat_publicerat/ Artiklar_PV/ER04_2.pd [Accessed on 19 June 2005].

11 PARKIN, M. (1999) Economics, $5^{\text {th }}$ ed. AddisonWesley: United States of America.

12 RESERVE BANK OF NEW ZEALAND (2005) J5 Marketscope Survey: Expectations of inflation, Available online at http//.www.rbnz.govt.nz [Accessed 8 June 2005].

13 ROSSOUW, J. (2005) "Monetêre beleid in SuidAfrika sedert 1965: Die vordering vanaf direkte beheer tot inflasieteikens", Tydskrif vir Geesteswetenskappe, Suid-Afrikaanse Akademie vir Wetenskap en Kuns, Junie, Jaargang 45:2.

14 ROSSOUW, J. \& JOUBERT, F. (2005) "Supporting an inflation targeting policy with the measurement of inflation credibility", The South African Journal of Economics, June, 73:2.

15 STATISTICAL ANALYSIS SYSTEM (SAS) FOR WINDOWS (1999-2001) Version 8.2, United States of America: SAS Institute Inc.

16 SVERIGES RIKSBANK ([S.a]). Inflation expectations. Available online at http:// www.riksbank.com/templates/ Page.aspx?id=10551 [Accessed on 1 July 2005]. 


\section{Annexure A \\ Questionnaire for use to establish the credibilty of published official inflation figures}

Your co-operation in the compilation of this questionnaire will be appreciated

Student group:

Name:

Student number:

\section{Question 1}

South Africa's official rate of inflation for inflation (CPI) was 3.0 per cent in March 2005. Is this a true reflection of average price increases?

$$
\text { YES }
$$

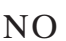

\section{Annexure B}

Questionnaire for use to establish the credibilty of published official inflation figures used for inflation targeting purposes

Your co-operation in the compilation of this questionnaire will be appreciated

Student group:

Name:

Student number:

\section{Question 1}

South Africa's official rate of inflation for inflation targeting purposes (CPIX) was 3.6 per cent in March 2005. Is this a true reflection of average price increases? 
Annexure C

Analysis of questionnaires used to establish the credibilty of official inflation figures (CPI)

\begin{tabular}{lc}
\hline & EKN 215 \\
Respondents & 42 \\
Acceptance (number) & 35 \\
Barometer reading & 7 \\
& $\begin{array}{c}\text { Annexure D } \\
\text { Analysis of questionnaires used to establish the credibilty } \\
\text { of official inflation figures for targeting purposes (CPIX) }\end{array}$ \\
\hline
\end{tabular}

Respondents

EKN 215

Acceptance (number)

39

26

Barometer reading

13 